\title{
Purification efficacy of different parts of Mangifera indica on water samples from contaminated drinking water sources in chanchaga local government area of Niger State, Nigeria
}

\author{
Mary Banke Okunlola ${ }^{1}$. Udeme Josiah Joshua Jjah $^{1} \cdot$ Jonathan Yisa $^{2} \cdot$ Peter Olabisi Abioye $^{1}$. \\ Damola Stephen Ariyeloye ${ }^{3}$. Julius Ndayaman Ibrahim ${ }^{4}$
}

Received: 27 June 2019 / Accepted: 24 March 2020 / Published online: 6 April 2020

(c) The Author(s) 2020

\begin{abstract}
The use of natural coagulant in water purification has gain popularities owing to the public health consequences of consuming untreated water and the carcinogenic properties of synthetic coagulant. In the present study, the leaf, stem, seed and bark powdered samples Mangifera indica were used to treat contaminated river, stream and pond water at concentrations of 0.1, $0.2,0.3,0.4$ and $0.5 \mathrm{~g} / \mathrm{L}$. Microbial quality and physicochemical properties of the water samples were investigated after 0 , 12 and $24 \mathrm{~h}$ of treatment. The results showed that the addition of $M$. indica considerably decreases or even eliminated (in most cases) the aerobic heterotrophic bacteria, coliforms, salmonella and shigella in the water samples. All parts of $M$. indica tested decreased the $\mathrm{pH}$, dissolve oxygen, total dissolved solid, calcium, nitrate, turbidity and chemical oxygen demand contents of the water samples when compared with untreated water. The activities of the plant materials increase with increase treatment time and concentrations. In conclusion, the raw surface water (stream, river and pond) used for the study fall short of standard. Mangifera indica leaf, stem, seed and bark materials improved the quality of the raw surface water based on the maximum permissible limit of microbial load and physicochemical parameters. This could serve as a cheaper and safer alternative to the synthetic coagulant.
\end{abstract}

Keywords Phytochemicals $\cdot$ Mangifera indica $\cdot$ Antimicrobial $\cdot$ Physicochemical $\cdot$ River $\cdot$ Stream $\cdot$ Pond

\section{Introduction}

Water is a basic human necessity for well-being and a healthy life. However, the level of water purity being consumed is very essential since it has a direct effect on health. About $75 \%$ of the world population lives in developing countries, out of which 1.2 billion people particularly in East Asia, South Asia and sub-Saharan Africa are still

Mary Banke Okunlola

bankeokunlolla@gmail.com

1 Department of Microbiology, Federal University of Technology, Minna, Niger State, Nigeria

2 Department of Chemistry, Federal University of Technology, Minna, Niger State, Nigeria

3 Department of Biochemistry, Federal University of Technology, Akure, Ondo State, Nigeria

4 Department of Biological Sciences, Federal Polytechnic, Bida, Niger State, Nigeria lacking safe drinking water (Megersa et al. 2014; UNICEF 2010). Pollution of these waters can occur via natural and human sources including industrial effluent, agricultural runoff, human and animal faeces. In addition, unhygienic transport, and domestic handling of water within the home can contaminate previously safe water (WHO 2006). These contaminated waters harboured thousands of pathogenic and diseases causing microorganisms, such as bacteria, viruses, protozoa and helminths), resulting in varieties of water borndiseases such as diarrhoea, cholera, typhoid and dysentery (Pritcharda et al. 2009). Consumption of these contaminated water has caused a serious public health challenge, accounting for 4 billion annual cases of diarrhoea and 1.8 million mortalities, mostly in children under the age of five (UNESCO 2007). In Nigeria, the most common source of drinking water for the rural population are from ponds, well, rivers stream and borehole water. This groundwater is usually consumed without any treatment whatsoever (Megersa et al. 2014). 
Imported chemicals used for conventional water purification to ensure potable water quality are expensive for developing countries including Nigeria (Abatneh et al. 2014). In addition to the high cost of importing chemicals for water treatment, the most available and affordable chemicals coagulant like alum (aluminium sulphate), have been associated with carcinogenic effect (Tröltzsch and Otto 2017). Consequently, these threatened the well-being of the consumers, while those who chose to avoid such chemical treatment end up taking the untreated water which also poses a threat to their health.

The uses of natural plant materials including seeds, sap, bark leaves, fruits and roots of trees and plants for water purification has been well practiced for many centuries (Anwar and Rashid 2007). These plant materials offered several advantages of cost-effectiveness, biodegradability and safe to human health (Yusuf et al. 2018a), as opposed to synthetic chemicals such as Alum (Aho and Lagasi 2012).

Mangifera indica has been reportedly used as water coagulant in traditional water purification system. In addition to the well-documented antimicrobial activities of $M$. indica (Oluduro et al. 2010; Singh et al. 2010), it also possessed numerous health benefits including anti-ulcer, antidiarrhoea, diuretic, anti-hypertensive, anti-cancer activities and antiparasitic activities (Meran et al. 2017). Thus, as a solution to the aforementioned, $M$. indica could serve an alternative natural coagulant to replace synthetic aluminum thus increasing the safety and suitability of water for human consumption. The present study therefore aimed at evaluating the effect of seed, leaves, bark and stem materials of $M$. indica on the microbial quality and physicochemical properties of river, stream, pond and well water samples from Chanchaga Local Government area, Niger State, Nigeria.

\section{Materials and methods}

\section{Sample collection}

Seeds, roots, bark and leaves of Mangifera indica were collected from Bosso Local Government Area of Niger State. The plant materials were identified at and authenticated at National Institute for Pharmaceutical Research and Development (NIPRID) Abuja where the vouchers number (NIPRD/H/7023) was deposited.

\section{Processing of plant materials}

The plant materials were air-dried under ambient temperature at Microbiology Laboratory Federal University of Technology, Minna, Nigeria. The dried plant materials were pulverized into fine powder, filtered using sieve of mesh size
$0.8 \mathrm{~mm}$. The powder samples were stored in an air tight container at ambient temperature until required for use.

\section{Qualitative phytochemical screening of the plant materials}

Preliminary qualitative phytochemical screening which involved performing simple chemical tests to detect the presence of secondary metabolites, including tannins, flavonoids, phenols, alkaloids, saponins and glycosides, was carried out in accordance with the method described by Harborne (1998), and Trease and Evans (1983).

\section{Collection of water samples}

The sampling sites selected for the purpose of this study were Chanchaga River, Angwakopini Stream and Rugakafi Pond in Niger State Nigeria. The samples were collected where people commonly collect water for their domestic activities. Standard sampling methods of APHA (1999) were adopted in the collection of the water samples. Water samples for physicochemical analyses were collected using transparent sterile containers of $2.0 \mathrm{~L}$ capacity. The plastic containers were thoroughly washed with $5 \%$ nitric acid $\left(\mathrm{HNO}_{3}\right)$ and rinsed with tap water (WHO 2011). They were later rinsed thoroughly with deionized water and allowed to dry before use.

\section{Screening of plant materials for potential to purify water}

In each treatment case, a solution was prepared by dissolving $0.1 \mathrm{~g}, 0.2 \mathrm{~g}, 0.3 \mathrm{~g}, 0.4 \mathrm{~g}$ and $0.5 \mathrm{~g}$ of each powder sample in $100 \mathrm{~mL}$ of sterile distilled water. The solution was shaken for five minutes and poured into $900 \mathrm{~mL}$ of water sample, made up to 1 litre and allowed to stand for $30 \mathrm{~min}$ to allow the coagulated particles to settle to the bottom. The supernatant was poured through a filter paper to ensure that any suspended coagulant is trapped (McConnachie et al. 1999). The supernatant was then subjected to microbial and physicochemical analysis. Based on the volume of water, appropriate different concentration of alum and calcium hypochlorite was introduced into water sample and allowed to stand for some hour, after which the water was subjected to both microbiological and physiological analysis to compare its efficiency of water treatment with the plant materials.

\section{Bacteriological analysis of water}

Membrane filtration technique was employed to determine microbial quality of the water samples in accordance with American Public Health Association (APHA 1999). Analyses were carried out to determine total viable counts (TVC), 
total coliform counts (TCC) and faecal coliform counts (FCC). TVC, TCC and FCC were determined by using lauryl sulphate broth (MLSB) medium, Salmonella shigella counts using Salmonella Shigella agar (SSA).

\section{Identification of Bacterial Isolates}

Isolates from the plates were identified further by biochemical tests, using the method of Vandepitte et al. (2003) and Cheesbrough (2008). Morphological and biochemical tests carried out included Gram staining, catalase, oxidase, indole tests, urease production, methyl red, Voges-Proskauer, $\mathrm{H}_{2} \mathrm{~S}$ production, coagulase, starch hydrolysis, lactose and citrate utilization, mannitol, sucrose and glucose tests.

\section{Physicochemical Analyses of the Water Samples}

The physicochemical parameters of the water were analyzed using the standard procedures outlined in the Standard Method for the Examination of Water and Wastewater (APHA 1999) to check the pH, conductivity, hardness, turbidity, total dissolved solid (TDS), biological oxygen demand (BOD), chemical oxygen demand (COD), nitrate, chloride, calcium and magnesium.

\section{Statistical analysis}

Data collected were subjected to statistical analysis using the Statistical Package For Social Science (SPSS) version 21.0 and expressed as mean \pm standard error of mean (SEM). Differences between groups were compared using analysis of variance, ANOVA $(P<0.05)$ followed by Duncan's multiple range test. Differences in mean were considered to be significant $5 \%$ level of significance.

\section{Results}

\section{Phytochemicals}

The qualitative phytochemical composition of the seed, leaf, bark and stem of Mangifera indica is presented in Table 1 . Results revealed the presence of alkaloids, steroids, cardiac glycosides, phenol, flavonoids, saponins, tannins, cardiac glycosides and anthraquinone and terpenes.

\section{Effect of Mangifera indica leaf, seed, stem and bark powder on bacterial quality of water samples}

\section{Stream water}

The leaf and bark materials of Mangifera indica at concentrations of $0.2,0.3,0.4$ and $0.5 \mathrm{~g} / \mathrm{L}$ completely eliminated
Table 1 Phytochemical composition of Mangifera indica used for water purification

\begin{tabular}{lcccc}
\hline & Leaf & Seed & Stem & Bark \\
\hline Phenol & + & + & + & + \\
Flavonoids & + & + & + & + \\
Saponins & + & + & + & + \\
Tannin & + & + & + & + \\
Alkaloids & + & + & + & + \\
Cardiac glycoside & + & + & + & + \\
Anthraquinone & + & + & + & + \\
Terpenes & + & + & + & + \\
Steroids & + & + & + & + \\
\hline
\end{tabular}

Key: + (Present)

the coliforms, Salmonella and Shigella in the stream water after $12 \mathrm{~h}$ of treatment. The stem material at concentrations of $0.3,0.4$ and $0.5 \mathrm{~g} / \mathrm{L}$ completely eliminated the bacteria of the stream water after $12 \mathrm{~h}$ of treatment. However, the seed material was less active, eliminating bacteria after $24 \mathrm{~h}$ only at 0.4 and $0.5 \mathrm{~g} / \mathrm{L}$ (Table 2). Treatment of stream water with alum and calcium hypochlorite completely eliminated the bacteria after $24 \mathrm{~h}$.

\section{Pond water}

The leaf and bark materials of Mangifera indica at concentrations of $0.2,0.3,0.4$ and $0.5 \mathrm{~g} / \mathrm{L}$ completely eliminated the various bacteria from the pond water after $12 \mathrm{~h}$ of treatment. The stem material was least active and caused complete elimination of total viable bacteria, coliforms, Salmonella and Shigella only after $24 \mathrm{~h}$ of treatment. However, the seed material was able to eliminate the organisms only at $0.5 \mathrm{~g} / \mathrm{L}$ concentrations after $24 \mathrm{~h}$ treatment (Table 3).

\section{River water}

Treatment of river water with alum and calcium hypochlorite completely eliminated the bacteria after $24 \mathrm{~h}$. The powdered leaf material of Mangifera indica at concentrations of 0.3, 0.4 and $0.5 \mathrm{~g} / \mathrm{l}$ completely eliminated the coliforms from the river water after $12 \mathrm{~h}$ of treatment, while all concentrations tested caused complete elimination of faecal coliforms, Salmonella and Shigella after $12 \mathrm{~h}$ of treatment. The bark and the stem materials at all concentrations tested caused complete elimination of the various bacteria after $24 \mathrm{~h}$. However, the seed material was less active causing elimination of the bacteria only at 0.4 and 0.5 concentrations after $24 \mathrm{~h}$ treatment (Table 4). 


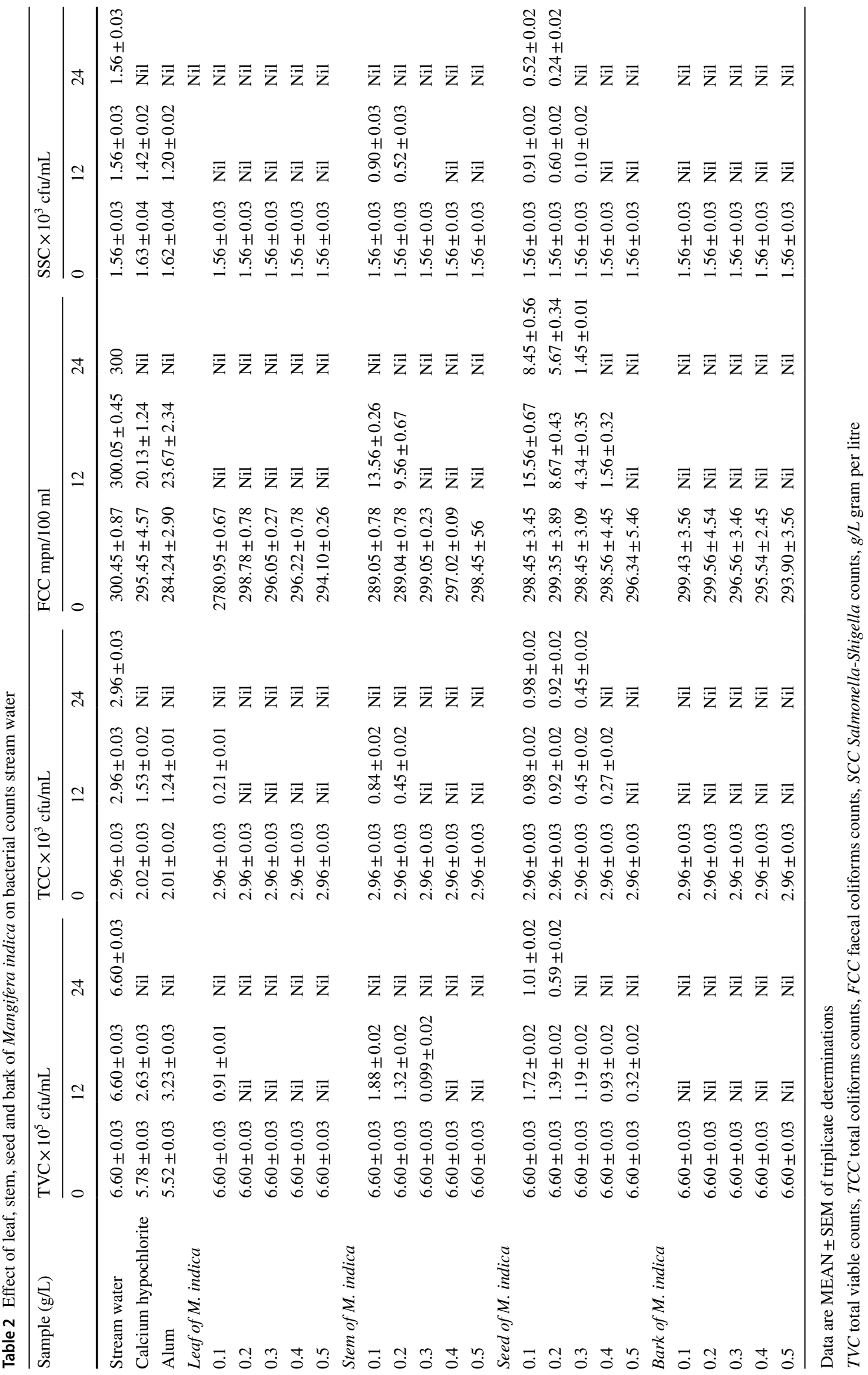




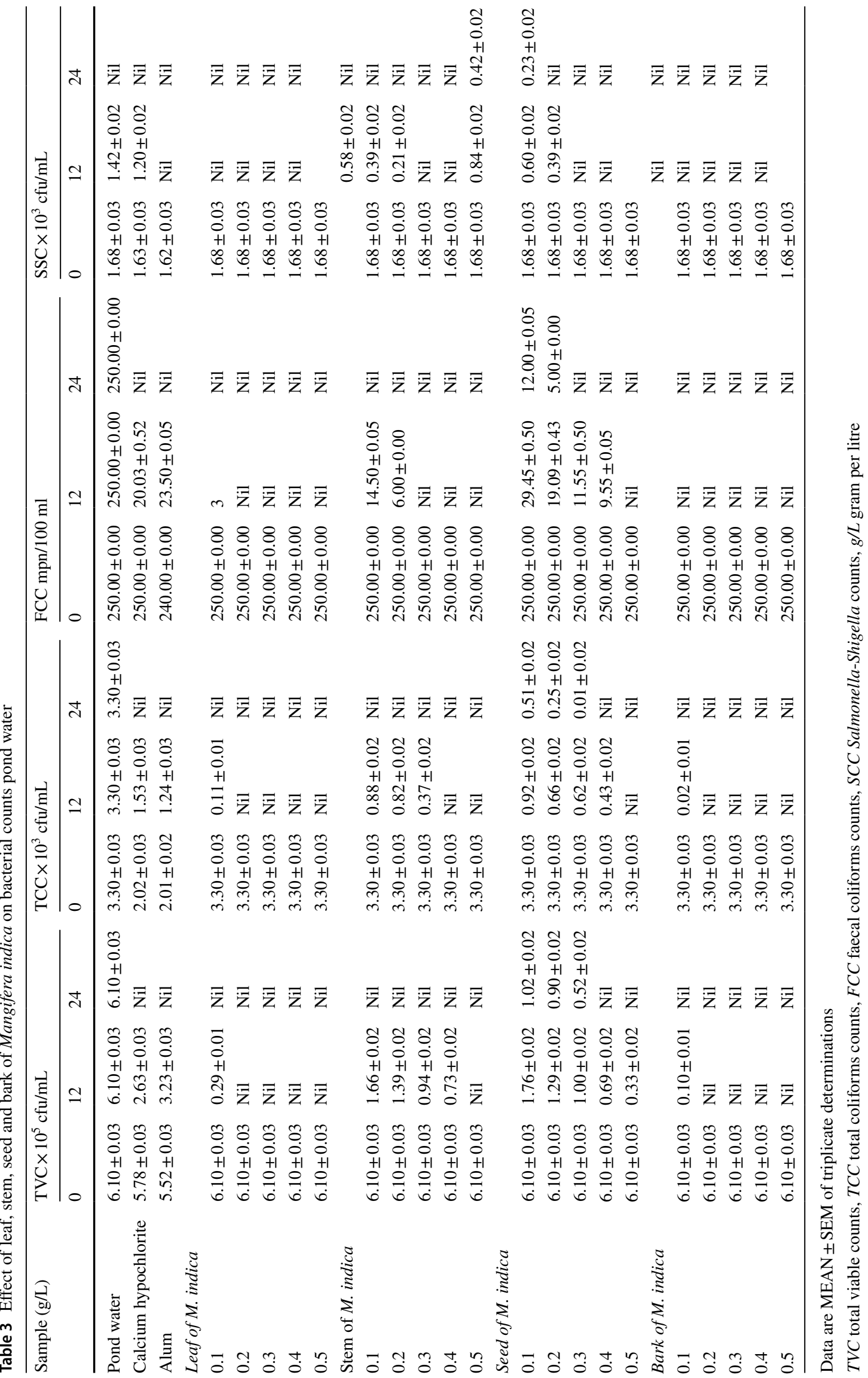




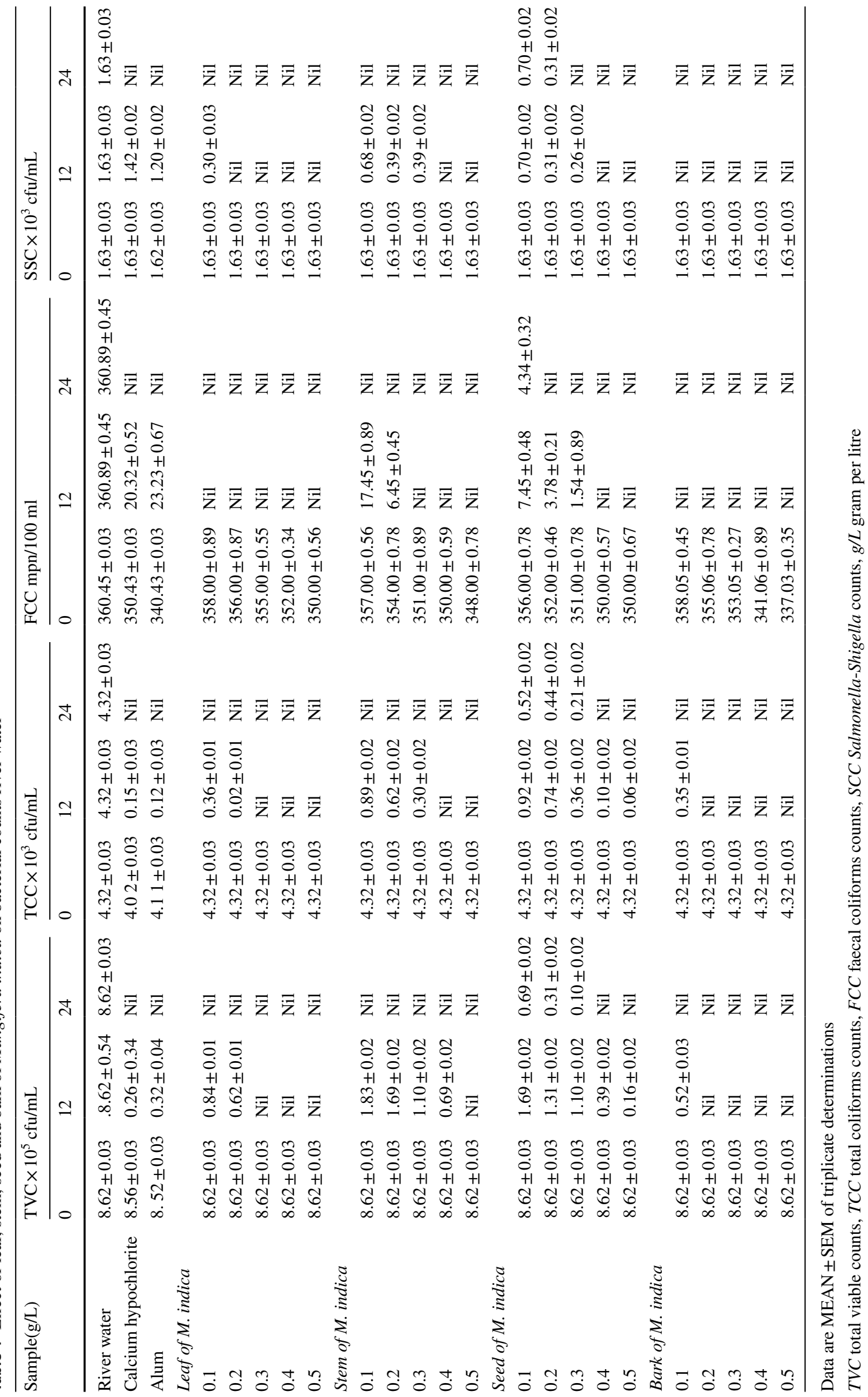




\section{Effect of Mangifera indica treatment on Physicochemical qualities of Water Samples}

\section{Physicochemical properties of water samples treated} with leaf, stem, seed and bark materials of Mangifera indica

Pond water The leaf, stem, seed and bark materials of Mangifera indica had no effect on temperature, COD, chloride, nitrate and magnesium but decreased the turbidity, calcium and water hardness of the pond water. However, leaf material increased the conductivity from $184.90 \pm 2.34$ to $327.43 \pm 4.78 \mu \mathrm{S} / \mathrm{cm}$ and decreased the TDS of the pond water sample from $134.78 \pm 2.34$ to $105.32 \pm 2.89 \mathrm{mg} / \mathrm{l}$ (Table 5).

River water Treatment of river water with Mangifera indica showed no significant effect $(p>0.05)$ on the temperature, DO, calcium, nitrate, COD and turbidity when compared with the untreated river water. All part of Mangifera indica used significantly $(p<0.05)$ reduced the $\mathrm{pH}$ (except for the seed material), hardness and chloride but increased the conductivity of the river water sample. Treatment with alum significantly $(p<0.05)$ decreased the $\mathrm{pH}$ but increased the conductivity and chloride content of the water, while calcium hypochlorite significantly $(p<0.05)$ increased the TDS, calcium and chloride when compared with the untreated river water (Table 6).

Stream water Treatment of the stream water with stem, seed, leaf and bark powder material of Mangifera indica decreased the $\mathrm{pH}, \mathrm{DO}$, TDS, calcium, nitrate, turbidity and COD contents of the stream water when compared with untreated stream water (Table 7). Treatment of stream water with alum significantly $(p<0.05)$ decreased $\mathrm{pH}(6.25 \pm 3.50)$, DO $(6.25 \pm 3.50 \mathrm{mg} / \mathrm{l})$, nitrate $(12.53 \pm 2.56 \mathrm{mg} / \mathrm{l})$ and turbidity $(5.38 \pm 2.58 \mathrm{NTU})$ but increased the conductivity $(365.50 \pm 3.80 \mu \mathrm{S} / \mathrm{cm})$, calcium $(97.50 \pm 3.80 \mathrm{mg} / \mathrm{l})$ and magnesium $(78.25 \pm 1.75 \mathrm{mg} / \mathrm{l})$ content when compared with the untreated stream water. Calcium hypochlorite, on the other hand, decreased the DO $(6.73 \pm 0.56 \mathrm{mg} / \mathrm{l})$, nitrate and increased conductivity $(365.50 \pm 3.80 \mu \mathrm{S} / \mathrm{cm})$ and calcium $(85.41 \pm 3.41 \mathrm{mg} / \mathrm{l})$ of stream water when compared with untreated water.

\section{Minimum inhibitory concentrations (MIC) and minimum bactericidal concentrations $\mathrm{MBC}$ )}

The minimum inhibitory concentrations (MIC) and minimum bactericidal concentrations of the plant materials against Escherichia coli, Bacillus megaterium, Shigella dysenteriae, Brenner iaquercina, Pseudomonas aeruginasa, Enterobacter aerogenes, Salmonella spp, Proteus myxofaciens, Klebsiella oxytoca, Klebsiella pneumonia, Kluyvera ascorbata, Proteus mirabilis and Staphylococcus aureus isolated from river, stream and ponds water samples (Table 8). The minimum inhibitory concentrations (MIC) of the powdered seed, leaf, bark and stem materials of Mangifera indica range between 8 and $32 \mathrm{mg} / \mathrm{mL}$ against all the isolates tested. The minimum bactericidal concentrations (MBC) ranged from $8-64 \mathrm{mg} / \mathrm{mL}$ against all organism tested (Table 8).

Table 5 Physicochemical properties of pond water sample treated with powdered leaf, stem, seed and bark of Mangifera indica

\begin{tabular}{lrrrrrrr}
\hline Parameters & \multicolumn{1}{l}{ Untreated } & \multicolumn{1}{l}{ Alum } & Calcium hypochlorite & Stem & \multicolumn{2}{l}{ Seed } & Leaf \\
\hline pH & $9.30 \pm 0.02^{\mathrm{b}}$ & $8.20 \pm 1.30^{\mathrm{a}}$ & $9.10 \pm 0.46^{\mathrm{b}}$ & $7.62 \pm 1.53^{\mathrm{a}}$ & $9.42 \pm 1.65^{\mathrm{b}}$ & $8.92 \pm 0.54^{\mathrm{ab}}$ & $9.53 \pm 0.65^{\mathrm{b}}$ \\
DO (mg/l) & $8.67 \pm 0.45^{\mathrm{b}}$ & $6.73 \pm 2.50^{\mathrm{a}}$ & $6.73 \pm 0.56^{\mathrm{a}}$ & $7.52 \pm 1.63^{\mathrm{ab}}$ & $8.22 \pm 2.52^{\mathrm{b}}$ & $7.52 \pm 1.07^{\mathrm{ab}}$ & $8.32 \pm 2.01^{\mathrm{b}}$ \\
TDS (mg/l) & $134.78 \pm 2.34^{\mathrm{b}}$ & $113.20 \pm 2.50^{\mathrm{a}}$ & $113.24 \pm 4.97^{\mathrm{a}}$ & $135.06 \pm 2.76^{\mathrm{b}}$ & $135.21 \pm 2.44^{\mathrm{b}}$ & $105.32 \pm 2.89^{\mathrm{a}}$ & $155.21 \pm 2.60^{\mathrm{b}}$ \\
Conductivity $(\mu \mathrm{S} / \mathrm{cm})$ & $184.90 \pm 2.34^{\mathrm{b}}$ & $187.90 \pm 2.50^{\mathrm{b}}$ & $187.21 \pm 4.32^{\mathrm{b}}$ & $107.07 \pm 2.54^{\mathrm{a}}$ & $167.09 \pm 1.45^{\mathrm{b}}$ & $327.43 \pm 4.78^{\mathrm{c}}$ & $167.21 \pm 4.55^{\mathrm{b}}$ \\
Temp. $\left({ }^{\circ} \mathrm{C}\right)$ & $33.96 \pm 2.45^{\mathrm{a}}$ & $32.25 \pm 2.70^{\mathrm{a}}$ & $32.62 \pm 2.32^{\mathrm{a}}$ & $32.22 \pm 2.52^{\mathrm{a}}$ & $32.52 \pm 2.89^{\mathrm{a}}$ & $32.42 \pm 2.65^{\mathrm{a}}$ & $32.52 \pm 2.70^{\mathrm{a}}$ \\
Hardness (mg/l) & $694.97 \pm 8.34^{\mathrm{b}}$ & $342.50 \pm 2.60^{\mathrm{a}}$ & $654.32 \pm 5.43^{\mathrm{b}}$ & $438.4 \pm 2.56^{\mathrm{a}}$ & $318.3 \pm 2.45^{\mathrm{a}}$ & $408.54 \pm 2.32^{\mathrm{a}}$ & $302.32 \pm 2.52^{\mathrm{a}}$ \\
Calcium (mg/l) & $89.24 \pm 2.45^{\mathrm{a}}$ & $184.30 \pm 1.65^{\mathrm{b}}$ & $85.41 \pm 3.43^{\mathrm{b}}$ & $79.43 \pm 4.65^{\mathrm{b}}$ & $89.32 \pm 2.90^{\mathrm{b}}$ & $69.43 \pm 1.89^{\mathrm{a}}$ & $79.21 \pm 2.45^{\mathrm{b}}$ \\
Chloride (mg/l) & $20.01 \pm 2.34^{\mathrm{a}}$ & $19.55 \pm 2.50^{\mathrm{a}}$ & $20.54 \pm 2.35^{\mathrm{a}}$ & $20.32 \pm 0.56^{\mathrm{a}}$ & $25.52 \pm 0.70^{\mathrm{b}}$ & $20.42 \pm 0.78^{\mathrm{a}}$ & $20.52 \pm 0.65^{\mathrm{a}}$ \\
Nitrate (mg/l) & $13.53 \pm 1.45^{\mathrm{b}}$ & $12.50 \pm 2.40^{\mathrm{b}}$ & $12.53 \pm 3.45^{\mathrm{b}}$ & $10.32 \pm 0.87^{\mathrm{a}}$ & $13.52 \pm 0.87^{\mathrm{b}}$ & $12.32 \pm 0.74^{\mathrm{b}}$ & $11.22 \pm 0.89^{\mathrm{ab}}$ \\
Magnesium (mg/l) & $65.78 \pm 1.78^{\mathrm{ab}}$ & $73.43 \pm 1.60^{\mathrm{b}}$ & $64.21 \pm 1.56^{\mathrm{a}}$ & $56.43 \pm 2.43^{\mathrm{a}}$ & $66.32 \pm 1.54^{\mathrm{ab}}$ & $66.21 \pm 2.98^{\mathrm{ab}}$ & $56.54 \pm 2.62^{\mathrm{a}}$ \\
Turbidity (NTU) & $9.61 \pm 0.45^{\mathrm{b}}$ & $7.78 \pm 1.58^{\mathrm{a}}$ & $9.61 \pm 0.32^{\mathrm{b}}$ & $8.53 \pm 0.43^{\mathrm{a}}$ & $9.12 \pm 0.76^{\mathrm{a}}$ & $9.52 \pm 0.87^{\mathrm{a}}$ & $9.32 \pm 0.96^{\mathrm{a}}$ \\
COD (mg/l) & $88.90 \pm 1.56^{\mathrm{b}}$ & $86.09 \pm 0.80^{\mathrm{b}}$ & $84.02 \pm 2.45^{\mathrm{b}}$ & $9.42 \pm 0.74^{\mathrm{a}}$ & $61.42 \pm 2.52^{\mathrm{b}}$ & $61.42 \pm 4.99^{\mathrm{b}}$ & $55.44 \pm 4.87^{\mathrm{b}}$ \\
\hline
\end{tabular}

Data are MEAN \pm SEM of triplicate determinations

$C O D$ chemical oxygen demand, TDS total dissolved solid, $D O$ dissolved oxygen, $N T U$ nephelometric turbidity units, $\mu \mathrm{S} / \mathrm{cm}$ micro-Siemens per centimeter, $m g / L$ milligram per litre

Values followed by different superscript are significantly different $(p<0.05)$ 
Table 6 Physicochemical properties of river water sample treated with powdered leaf, stem, seed and bark of Mangifera indica

\begin{tabular}{|c|c|c|c|c|c|c|c|}
\hline Parameters & River & Alum & $\begin{array}{l}\text { Calcium hypochlo- } \\
\text { rite }\end{array}$ & Stem & Seed & Leaf & Bark \\
\hline $\mathrm{pH}$ & $9.57 \pm 1.75^{\mathrm{b}}$ & $7.45 \pm 0.58^{a}$ & $9.10 \pm 0.46^{\mathrm{b}}$ & $8.33 \pm 0.65^{\mathrm{ab}}$ & $9.33 \pm 0.45^{\mathrm{b}}$ & $7.32 \pm 0.65^{\mathrm{a}}$ & $8.24 \pm 0.56^{\mathrm{ab}}$ \\
\hline $\mathrm{DO}(\mathrm{mg} / \mathrm{l})$ & $6.38 \pm 2.17^{\mathrm{a}}$ & $6.75 \pm 0.55^{\mathrm{a}}$ & $6.73 \pm 0.56^{\mathrm{a}}$ & $9.42 \pm 0.88^{\mathrm{a}}$ & $8.33 \pm 0.65^{\mathrm{a}}$ & $8.43 \pm 0.99^{a}$ & $8.43 \pm 0.65^{\mathrm{a}}$ \\
\hline TDS (mg/l) & $115.21 \pm 1.02^{\mathrm{a}}$ & $113.07 \pm 0.77^{\mathrm{a}}$ & $113.24 \pm 4.97^{b}$ & $132.43 \pm 3.78^{\mathrm{a}}$ & $135.21 \pm 3.78^{\mathrm{a}}$ & $152.32 \pm 2.69^{b}$ & $144.21 \pm 2.87^{\mathrm{ab}}$ \\
\hline $\begin{array}{l}\text { Conductivity }(\mu \mathrm{S} / \\
\mathrm{cm})\end{array}$ & $169.55 \pm 2.83^{\mathrm{a}}$ & $262.06 \pm 0.57^{b}$ & $187.21 \pm 4.32^{\mathrm{ab}}$ & $187.32 \pm 1.87^{b}$ & $197.32 \pm 4.88^{b}$ & $187.21 \pm 2.76^{b}$ & $187.21 \pm 3.88^{b}$ \\
\hline Temp. $\left({ }^{\circ} \mathrm{C}\right)$ & $33.42 \pm 2.45^{\mathrm{a}}$ & $32.24 \pm 1.57^{\mathrm{a}}$ & $32.62 \pm 2.32^{\mathrm{a}}$ & $33.77 \pm 0.80^{\mathrm{a}}$ & $33.22 \pm 0.89^{\mathrm{a}}$ & $33.34 \pm 0.54^{\mathrm{a}}$ & $32.34 \pm 0.76^{\mathrm{a}}$ \\
\hline Hardness (mg/l) & $652.23 \pm 2.56^{\mathrm{b}}$ & $312.30 \pm 2.58^{\mathrm{a}}$ & $654.32 \pm 5.43^{b}$ & $312.21 \pm 0.56^{\mathrm{a}}$ & $312.21 \pm 2.90^{\mathrm{a}}$ & $312.21 \pm 3.54^{\mathrm{a}}$ & $362.21 \pm 1.89^{\mathrm{a}}$ \\
\hline Calcium (mg/l) & $85.40 \pm 2.89^{\mathrm{a}}$ & $85.05 \pm 0.78^{\mathrm{a}}$ & $120.41 \pm 3.43^{b}$ & $84.32 \pm 3.89^{\mathrm{a}}$ & $78.43 \pm 1.65^{\mathrm{a}}$ & $84.21 \pm 1.69^{\mathrm{a}}$ & $84.46 \pm 3.86^{\mathrm{a}}$ \\
\hline Chloride (mg/l) & $19.52 \pm 1.74^{\mathrm{a}}$ & $87.08 \pm 3.87^{b}$ & $86.54 \pm 2.35^{b}$ & $20.52 \pm 1.54^{b}$ & $21.52 \pm 3.65^{b}$ & $17.52 \pm 3.89^{\mathrm{a}}$ & $19.53 \pm 4.90^{b}$ \\
\hline Nitrate $(\mathrm{mg} / \mathrm{l})$ & $10.61 \pm 1.45^{\mathrm{a}}$ & $12.53 \pm 0.54^{\mathrm{a}}$ & $12.53 \pm 3.45^{\mathrm{a}}$ & $13.42 \pm 2.56^{\mathrm{a}}$ & $13.22 \pm 1.87^{\mathrm{a}}$ & $13.23 \pm 4.65^{\mathrm{a}}$ & $13.24 \pm 4.76^{\mathrm{a}}$ \\
\hline Magnesium (mg/l) & $63.12 \pm 1.20^{\mathrm{a}}$ & $64.47 \pm 0.59^{\mathrm{a}}$ & $64.21 \pm 1.56^{\mathrm{a}}$ & $56.32 \pm 1.77^{\mathrm{a}}$ & $73.34 \pm 3.88^{b}$ & $74.23 \pm 2.80^{\mathrm{b}}$ & $56.33 \pm 1.98^{\mathrm{a}}$ \\
\hline Turbidity (NTU) & $9.14 \pm 2.30^{b}$ & $4.38 \pm 0.87^{\mathrm{a}}$ & $9.61 \pm 0.32^{b}$ & $9.05 \pm 2.90^{\mathrm{a}}$ & $9.04 \pm 2.89^{\mathrm{a}}$ & $10.22 \pm 3.55^{\mathrm{a}}$ & $8.54 \pm 0.55^{\mathrm{a}}$ \\
\hline $\mathrm{COD}(\mathrm{mg} / \mathrm{l})$ & $81.23 \pm 2.50^{\mathrm{b}}$ & $64.08 \pm 0.76^{\mathrm{a}}$ & $84.02 \pm 2.45^{\mathrm{b}}$ & $61.33 \pm 2.65^{\mathrm{a}}$ & $63.35 \pm 2.70^{\mathrm{a}}$ & $63.33 \pm 4.76^{\mathrm{a}}$ & $61.33 \pm 2.45^{\mathrm{a}}$ \\
\hline
\end{tabular}

Data are $\mathrm{MEAN} \pm \mathrm{SEM}$ of triplicate determinations

$C O D$ chemical oxygen demand, TDS total dissolved solid, $D O$ dissolved oxygen, $N T U$ Nephelometric Turbidity Units, $\mu S / \mathrm{cm}$ micro-Siemens per centimeter, $m g / L$ milligram per litre

Values followed by different superscript are significantly different $(p<0.05)$

Table 7 Physicochemical properties of stream water sample treated with powdered leaf, stem, seed and bark of Mangifera indica

\begin{tabular}{lrrrrrrr}
\hline Parameters & \multicolumn{1}{l}{ Stream } & \multicolumn{1}{l}{ Alum } & Calcium hypochlorite & Stem & Seed & Leaf \\
\hline pH & $9.26 \pm 1.98^{\mathrm{b}}$ & $6.25 \pm 3.50^{\mathrm{a}}$ & $9.10 \pm 0.46^{\mathrm{b}}$ & $7.54 \pm 0.54^{\mathrm{a}}$ & $8.33 \pm 0.55^{\mathrm{a}}$ & $8.54 \pm 0.56^{\mathrm{a}}$ & $8.34 \pm 0.56^{\mathrm{a}}$ \\
DO (mg/l) & $8.36 \pm 1.19^{\mathrm{b}}$ & $6.25 \pm 3.50^{\mathrm{a}}$ & $6.73 \pm 0.56^{\mathrm{a}}$ & $8.34 \pm 0.66^{\mathrm{a}}$ & $9.34 \pm 1.54^{\mathrm{a}}$ & $8.34 \pm 0.66^{\mathrm{a}}$ & $8.34 \pm 0.55^{\mathrm{a}}$ \\
TDS (mg/l) & $140.35 \pm 2.87^{\mathrm{b}}$ & $328.35 \pm 2.36^{\mathrm{b}}$ & $113.24 \pm 4.97^{\mathrm{a}}$ & $145.43 \pm 2.67^{\mathrm{a}}$ & $145.32 \pm 2.76^{\mathrm{a}}$ & $145.54 \pm 3.77^{\mathrm{a}}$ & $140.32 \pm 4.67^{\mathrm{a}}$ \\
Conductivity ( $\mu \mathrm{S} / \mathrm{cm})$ & $185.73 \pm 2.76^{\mathrm{a}}$ & $365.50 \pm 3.80^{\mathrm{b}}$ & $187.21 \pm 4.32^{\mathrm{a}}$ & $178.43 \pm 3.66^{\mathrm{a}}$ & $184.43 \pm 7.55^{\mathrm{a}}$ & $178.54 \pm 3.78^{\mathrm{a}}$ & $182.43 \pm 5.76^{\mathrm{a}}$ \\
Temp. $\left({ }^{\circ} \mathrm{C}\right)$ & $33.45 \pm 1.98^{\mathrm{a}}$ & $32.27 \pm 3.59^{\mathrm{a}}$ & $32.62 \pm 2.32^{\mathrm{a}}$ & $32.44 \pm 3.67^{\mathrm{a}}$ & $33.23 \pm 3.67^{\mathrm{a}}$ & $32.43 \pm 4.65^{\mathrm{a}}$ & $33.44 \pm 1.89^{\mathrm{a}}$ \\
Hardness (mg/l) & $351.46 \pm 2.12^{\mathrm{a}}$ & $256.55 \pm 3.50^{\mathrm{a}}$ & $654.32 \pm 5.43^{\mathrm{b}}$ & $316.34 \pm 4.89^{\mathrm{a}}$ & $336.43 \pm 3.66^{\mathrm{a}}$ & $336.43 \pm 2.77^{\mathrm{a}}$ & $386.34 \pm 3.67^{\mathrm{a}}$ \\
Calcium (mg/l) & $86.31 \pm 2.24^{\mathrm{b}}$ & $97.50 \pm 3.80^{\mathrm{b}}$ & $85.41 \pm 3.43^{\mathrm{b}}$ & $66.54 \pm 3.55^{\mathrm{a}}$ & $63.54 \pm 3.87^{\mathrm{a}}$ & $68.63 \pm 4.53^{\mathrm{a}}$ & $63.54 \pm 3.66^{\mathrm{a}}$ \\
Chloride (mg/l) & $20.51 \pm 1.72^{\mathrm{a}}$ & $19.55 \pm 3.77^{\mathrm{a}}$ & $20.54 \pm 2.35^{\mathrm{a}}$ & $20.34 \pm 2.54^{\mathrm{a}}$ & $20.33 \pm 4.53^{\mathrm{a}}$ & $20.43 \pm 3.99^{\mathrm{a}}$ & $20.44 \pm 3.67^{\mathrm{a}}$ \\
Nitrate (mg/l) & $18.58 \pm 0.70^{\mathrm{b}}$ & $12.53 \pm 2.56^{\mathrm{a}}$ & $12.53 \pm 3.45^{\mathrm{a}}$ & $13.42 \pm 2.87^{\mathrm{a}}$ & $12.53 \pm 2.67^{\mathrm{a}}$ & $13.43 \pm 3.90^{\mathrm{a}}$ & $13.54 \pm 4.79^{\mathrm{a}}$ \\
Magnesium (mg/l) & $66.11 \pm 2.01^{\mathrm{a}}$ & $78.25 \pm 1.75^{\mathrm{b}}$ & $64.21 \pm 1.56^{\mathrm{a}}$ & $64.44 \pm 1.78^{\mathrm{a}}$ & $66.32 \pm .46^{\mathrm{a}}$ & $67.54 \pm 4.56^{\mathrm{a}}$ & $66.67 \pm 3.59^{\mathrm{a}}$ \\
Turbidity (NTU) & $9.53 \pm 1.09^{\mathrm{b}}$ & $5.38 \pm 2.58^{\mathrm{a}}$ & $9.61 \pm 0.32^{\mathrm{b}}$ & $9.53 \pm 2.89^{\mathrm{a}}$ & $8.53 \pm 2.43^{\mathrm{a}}$ & $9.54 \pm 3.32^{\mathrm{a}}$ & $9.34 \pm 3.78^{\mathrm{a}}$ \\
COD (mg/l) & $84.09 \pm 29^{\mathrm{b}}$ & $86.07 \pm 3.87^{\mathrm{b}}$ & $84.02 \pm 2.45^{\mathrm{b}}$ & $68.54 \pm 3.80^{\mathrm{a}}$ & $64.54 \pm 3.54^{\mathrm{a}}$ & $62.54 \pm 3.32^{\mathrm{a}}$ & $64.33 \pm 2.76^{\mathrm{a}}$ \\
\hline
\end{tabular}

Data are MEAN \pm SEM of triplicate determinations

$C O D$ chemical oxygen demand, TDS total dissolved solid, $D O$ dissolved oxygen, $N T U$ Nephelometric Turbidity Units, $\mu \mathrm{S} / \mathrm{cm}$ micro-Siemens per centimeter, $m g / L$ milligram per litre

Values followed by different superscript are significantly different $(p<0.05)$

\section{Discussion}

It was reported that crude material of medicinal plant contains significant amount of phytochemical with antimicrobial properties (Tsado et al. 2016; Ibrahim et al. 2017; Yusuf et al. 2018b); these phytochemicals have also been reported to enhance surface water purification. The medicinal properties of these plants particularly the antimicrobial properties will enhance microbial decontamination of water, thus making it fit for drinking and for other domestic or industrial application (Okunlola et al. 2020).

Interestingly, all the phytochemical investigated in this study were present in all parts of Mangifera indica. The result of phytochemical screening from this study shows similarities to several studies conducted in an attempt to determine phytochemical constituents of different part of M. indica (Aiyelaagbe and Osamudiamen 2009; Sanwaral and Susish 2013). The result was in conformity with study of Doughari and Manzara (2008) on in vitro antibacterial 
activity of crude leaf extract of $M$. indica, in which preliminary phytochemical analysis revealed the presence of tannins, glycosides, saponins and phenols. Other experiments conducted to determine the phytochemical constituents in Mangifera indica by Aiyelaagbe and Osamudiamen (2009), and Sanwaral and Susish (2013), showed the presence of alkaloid, flavonoids, tannins, saponins, glycosides and anthraquinones. These components are known to be biologically active because they protect the plant against infections and predation by animals.

Similarly, Pintu and Arna (2014) reported that aqueous extract of Mangifera indica young leaves contained tannins, alkaloids, steroid, carbohydrate, glycoside and flavonoid that may be responsible for the anti-diarrhoeal properties of the plant material. Pritesh and Dash (2015) reported that saponins may help to prevent colon cancer. Therefore, the microbial decontamination of stream, river and well water by $M$. indica observed in this study material may be attributable to the presence of the above phytochemicals.

However, on a contrary note Olasehinde et al. (2018) reported the absence of alkaloid and cardiac glycoside in aqueous leaf material of $M$. indica. This may be attributed to the differences in the method used in the extraction of the phytochemicals from the leaf of $M$. indica, i.e. Olasehinde et al. (2018) use hot extraction method, while cold aqueous extraction was employed in this study. Lawal et al. (2014) argued that the variations in the presence or absence of phytochemical constituents of plants could be attributed to the difference in polarity of the solvents used, method of extraction, duration of extraction or the period of the year the plant was obtained.

The mean viable counts, coliform counts for the river, stream and pond water samples recorded in this study were generally higher than the set standard for water meant for drinking purposes by WHO (2011). The presence of these high bacterial species in the water samples suggests that the water bodies in the study area have been contaminated with wastes either from human or animal origin (Megersa et al. 2014).

Interestingly, the leaf and bark materials of Mangifera indica at concentrations of $0.2,0.3,0.4$ and $0.5 \mathrm{~g} / \mathrm{L} \mathrm{com-}$ pletely eliminated the aerobic heterotrophic bacteria, coliforms, salmonella and shigella in the stream and pond water after $12 \mathrm{~h}$ of treatment. Similarly, for river water, the powdered leaf sample Mangifera indica at concentrations of 0.3 , 0.4 and $0.5 \mathrm{~g} / \mathrm{l}$ eliminated the TVC and TCC of the river water after $12 \mathrm{~h}$, while all concentration tested caused complete elimination of FCC and SSC after $12 \mathrm{~h}$ of treatment.

The high antimicrobial activity of $M$. indica is an indication that the leaf, stem, seed and bark of this plant are effective in decontamination of microbes in surface water, thus making the water safe for consumption as recommended by WHO 2011). This significant activity of $M$ indica could be 
attributed to its phytochemical composition particularly the alkaloid, flavonoid and tannins (Table 1) which have been reported to have antimicrobial activity. However, the seed material was less active as the bacteria were eliminated only at higher doses $(0.4$ and $0.5 \mathrm{~g} / \mathrm{L})$ after $24 \mathrm{~h}$ of treatment. This could be attributed to the earlier mentioned findings that the quality and quantity of antimicrobial agent in the plants varies according to the part of the plant (leaf, stem seed or root).

The activity of Mangifera indica could also be due to fact that the bioactive agents in $M$. indica are mainly positively charged amino acids that attract the negatively charged component such as bacteria thus reducing the bacterial load of the water samples. This is supported by previous studies by Oluduro et al (2010), where treatment with M. oleifera and $M$. indica showed bactericidal activity.

The MIC of the Mangifera indica material (seed, leaf, bark and stem) ranged between $8-32 \mathrm{mg} / \mathrm{mL}$ against all the isolates, whereas in previous study MIC range of mango leaf against the bacteria was $12.5-100 \mathrm{mg} / \mathrm{ml}$ (Doughari and Manzara, 2008). This variation may be due to the dependent of mango leaf composition on several factors including origin, age, storage conditions and type of processing methods. Singh et al. (2010) reported that stem bark of M. indica exhibited excellent antibacterial and anti-fungal activities (MIC $=0.08 \mathrm{mg} / \mathrm{mL}$ ) against Streptococcus pneumonia, Enterobacter aerogenes, Klebsiella pneumonia and Candida albicans. The potent activity of Mangifera indica might be due to the presence of a strong bioactive agent mangiferin that shows multiple mode of action against microorganism (Navarro et al. 2003).

Hydrogen ion concentrations of the untreated water samples in this study exceeded the maximum permissible limit for drinking water. The slight tendency towards acidic $\mathrm{pH}$ values observed when Mangifera indica powdered materials were used could be attributed to the presence of $\mathrm{H}^{+}$group in the acidic amino acid composition of Mangifera indica materials which is donated, thus making the solution acidic (Doer 2005).

The untreated river, stream and pond water evaluated in this study are very hard according to USEPA (2009) classification. The use of this water for laundry purpose will not be adequate as it will not lather with soap. However, the observed significant reductions in the level of water hardness following treatment with $M$. indica powdered materials reflect the water remediation quality of the plant. This reduction in water hardness may improve the usefulness of the water for laundry purposes; it may also reduce the cost of laundry as lesser amount of soap will be required for lather formation.

Nitrates ranged between $13.53 \pm 1.45$ (pond) and $10.61 \pm 1.45$ (river). This value exceeded the maximum permissible limit of the standards (WHO 2006). The high nitrate content of untreated water sample could cause hypoxic condition in infant due to interference with the ability of red blood cells to transport oxygen (Orlov and Karkouti 2015). The significant reduction in nitrate contents of the water samples after treatment with Mangifera indica therefore reduced the threat of nitrate intoxication thus making the water safe for human consumptions.

Highly mineralized waters are unsuitable for many industrialized applications (APHA 1999). However, the total dissolved solids ranged between $115.21 \pm 1.02 \mathrm{mg} / \mathrm{l}$ and $140.35 \pm 2.87 \mathrm{mg} / \mathrm{l}$. This value fell within the permissible limit of the standards suitable for drinking purpose. The significantly higher TDS in stream and pond water when compared with the river water is an indication that the stream and pond water are polluted or unhealthy (WHO 2011). Hence, removal of TDS is a primary factor. Fortunately, all parts of Mangifera indica tested significantly decreased TDS, thus improving the quality of the water.

\section{Conclusion}

The raw surface water (stream, river and pond) used for the study fall short of standard in terms of microbial load and the physicochemical properties. Mangifera indica leaf, stem, seed and bark materials contained bioactive compounds and improved the quality of the raw surface water based on the maximum permissible limit of microbial load and physicochemical parameters. This could serve as a cheaper and safer alternative to the synthetic coagulant.

Acknowledgements The authors would like to appreciate the Tertiary Educational Trust Fund of Nigerian and Federal University of Technology Minna for the research Grant (TETFUND/FUTMINNA)/2017/05).

Funding This research was supported by Tertiary Educational Trust Fund of Nigerian (TETFUND) Institutional-Based Research Intervention of Federal University of Technology, Minna (TETFUND/ FUTMINNA)/2017/05).

\section{Compliance with ethical standards}

Conflict of interest The authors declared that they have no conflict of interest.

Open Access This article is licensed under a Creative Commons Attribution 4.0 International License, which permits use, sharing, adaptation, distribution and reproduction in any medium or format, as long as you give appropriate credit to the original author(s) and the source, provide a link to the Creative Commons licence, and indicate if changes were made. The images or other third party material in this article are included in the article's Creative Commons licence, unless indicated otherwise in a credit line to the material. If material is not included in the article's Creative Commons licence and your intended use is not permitted by statutory regulation or exceeds the permitted use, you will need to obtain permission directly from the copyright holder. To view a copy of this licence, visit http://creativecommons.org/licenses/by/4.0/. 


\section{References}

Abatneh Y, Omprakash S, Seid Y (2014) Purification of drinking water by low cost method in Ethiopia. Appl Water Sci 4:357-362

Aho IM, Lagasi JE (2012) A new water treatment system using Moringa oleifera seed. Am J Sci Ind Res 3(6):487-492

Aiyelaagbe OO, Osamudiamen PM (2009) Phytochemical screening for active compounds in Mangifera indica leaves from Ibadan, Oyo State. Plant Sci Res Ibadan 2(1):11-13

American Public Health Association (APHA) (1999) Standard methods for the examination of water and waste waters, 20th edn. APHA, Washington D.C, p 1134

Anwar F, Rashid U (2007) Physico-chemical characteristics of Moringa oleifera seeds and seed oil from a wild provenance of Pakistan. Pak J Biol Sci 39:1443-1453

Cheesbrough M (2008) District laboratory practice in tropical countries part 2. Cambridge University Press, New Delhi, pp 62-70

Doer B (2005) Field guides for emergency water treatment with Moringa oleifera. www.cawst.org/technology/watertreatment/filtration biosandanphp.Accessed 11 Apr 2019

Doughari JH, Manzara S (2008) In vitro antibacterial activity of crude leaf extract of Mangifera indica Linn. Afr J Microbiol Res 2:67-72

Harborne JB (1998) Phytochemical methods: a guide to modern technique of plant Analysis, 3rd edn. Springer, London

Ibrahim AM, Lawal B, Abubakar AN, Tsado NA, Kontagora GN, Gboke GA, Berinyuy EB (2017) Antimicrobial and free radical scavenging potentials of $N$-hexane and ethyl acetate fractions of Phyllanthus Fraternus. Nig J Basic Appl Sci 25(2):06-11

Lawal B, Ossai PC, Shittu OK, Abubakar AN (2014) Evaluation of phytochemicals, proximate, minerals and anti-nutritional compositions of yam peel, maize chaff and bean coat. Inter J Appl Biol Res 6(2):01-17

McConnachie GL, Folkard GK, Mtawali MA, Sutherland JP (1999) Field trials of appropriate hydraulic flocculation processes. Wat. Res 33(6): 1425-1434

Megersa M, Beyene A, Ambelu A, Woldeab B (2014) The use of indigenous plant species for drinking water treatment in developing countries: a review. J Biodiv Environ Sci 53:269-281

Meran KE, Kamani HT, Sameera RS (2017) A review on ethnopharmacological applications, pharmacological activities, and bioactive compounds of Mangifera indica (Mango). Evid Based Comp Alter Med. https://doi.org/10.1155/2017/6949835

Navarro MC, Montilla MP, Cabo MM, Galisteo M, Cáceres A, Morales C, Berger I (2003) Antibacterial, antiprotozoal and antioxidant activity of the five plants used in Izabal for infectious diseases. Phytother Res 17:325-329

Okunlola BM, Ijah UJJ, Yisa J, Abioye OP (2020) Effect of Carica papaya materials on microbial and physicochemical qualities of river, stream and pond water. Polish J Nat Sci 35(1)

Olasehinde GI, Sholotan KJ, Openibo JO, Taiwo OS, Bello OA, Ajayi JB, Ayepola OO, Ajayi AA (2018) Phytochemical and antimicrobial properties of Mangifera indica leaf extracts. Covenant $\mathbf{J}$ Physical \& Life Sciences (CJPL) 6:1

Oluduro OA, Aderiye BI, Connolly JD, Akintayo ET, Famurewa O (2010) Characterization and antimicrobial activity of 4-(ß-dglucopyranosyl-4-a-1 rhamnopyranosyloxy)-benzyl thiocarboxamide; aA novel bioactive compound from Moringa oleifera seed extract. Folia Microbiol 55(5):422-426
Orlov D, Karkouti K (2015) The pathophysiology and consequences of red blood cell storage. Anaesthesia 70(1):29-37

Pintu KD, Arna P (2014) Effects of aqueous young leaves extract of Mangifera indica on gm (-) microorganisms causing gastro- intestinal disorders. Asian J Plant Sci Res 4(1):23-27

Pritcharda T, Mkandawireb A, Edmondsona JG, O'Neillc GK (2009) Potential of using plant extracts for purification of shallow well water in Malawi. Phys Chem Earth 34:799-805

Pritesh R, Dash ZS (2015) Preliminary studies on phytochemicals and cytotoxic activity of methanolic rhizome extract of Hedychium coronarium. J Pharmacog Phytoche 4(1):136-139

Sanwaral A, Sushil K (2013) Antibacterial activity of Mangifera indica leaves against drug resistant bacterial strain. Intern J Adv Res $\mathrm{I}(6): 82-86$

Singh M, Khatoon S, Singh S, Kumar V, Rawat AK, Mehrotra S (2010) Antimicrobial screening of Ethnobotanically important stem bark of medicinal plants. Pharmacogn Res 2:254-257

Trease GE, Evans WC (1983) Textbook of pharmacognosy, 12th edn. Bailliere Tindall, London, p 34

Tröltzsch M, Otto S (2017) Pyogenic granuloma of the vermilion of the upper lip. Dtsch Arztebl Int 114:659. https://doi.org/10.3238/ arztebl.2017.0659

Tsado NA, Lawal B, Kontagora GN, Muhammad BM, Yahaya MA, Gboke JA, Muhammad UA, Hassan MK (2016) Antioxidants and antimicrobial- activities of methanol leaf extract of senna occidentalis. J Adv in Med Pharm Sci 8(2):1-7

UNESCO (2007) UNESCO water portal newsletter No. 161: Waterrelated Diseases. https://www.unesco.org/water/news/newsletter /161.shtml

UNICEF (2010) Progress on Sanitation and drinking water: 2010 Update. Joint Monitoring Programme for water supply and sanitation.

USEPA (2009) Basic Information on Long Term 2 Enhanced Surface Water Treatment Rule (online). https://www.epa.gov/OGWDW /disinfection/lt2/basicinformation.html. Accessed 25 June 2019

Vandepitte J, Verhaegen J, Engbaek K, Rohner P, Piot P, Heuck CC (2003) Basic laboratory procedures in clinical bacteriology, 2nd edn. World Health Organization Geneva, Switzerland, pp 42-59

WHO (2006) Guideline for drinking water quality incorporation first addendum. Vol. 1, Recommendations, 3rd ed. https://www.who. int/water.sanitation.health/dwh/qdwa0506.pdf. Accessed 15th Mar 2019.

WHO (World Health Organization) (2011) Emerging issues in water and infectious disease. World Health Organization, Geneva

Yusuf AA, Lawal B, Abubakar AN, Berinyuy EB, Omonije YO, Umar SI, Shebe MN, Alhaji YM (2018a) In-vitro antioxidants, antimicrobial and toxicological evaluation of Nigerian Zingiber officinale. Clinical Phytosci 4(12):1-8

Yusuf AA, Lawal B, Yusuf MA, Omonije YO, Adejoke AA, Raji FH, Wenawo DL (2018b) Free radical scavenging, antimicrobial activities and effect of sub-acute exposure to Nigerian Xylopia Aethiopica seed extract on liver and kidney functional indices of albino rat. Iran $\mathrm{j}$ toxicol 12(3):51-58

Publisher's Note Springer Nature remains neutral with regard to jurisdictional claims in published maps and institutional affiliations. 